\title{
An Extended Doctrine of Implied Consent - A Digital Mediator?
}

\author{
Georgia Jenkins
}

Accepted: 21 January 2021 / Published online: 23 March 2021

(C) The Author(s) 2021

\begin{abstract}
This article explores whether an extended doctrine of implied consent can better balance copyright interests in the digital environment, particularly users' access to digital content. Implied licences are analysed from a variety of jurisdictions including the United Kingdom, the European Union, Germany, the United States and Australia to submit that the role of implied consent emerges as a fundamental legal principle in both common and civil law jurisdictions. Given the significance of consent within the doctrine of exhaustion, the article also evaluates its application in the digital environment and the extent to which this could impact the proposal for an extended doctrine of implied consent. The boundaries of the extended doctrine along with its practical impact will be assessed through an example illustrating users' access and interaction with digital content. It then becomes clear from the discussion that follows, that an extended doctrine of implied consent has the potential to balance copyright interests in the digital environment due to its status as a fundamental legal principle and inherent flexibility to consider a range of factors regarding users' subsequent use of digital content.
\end{abstract}

Keywords Implied consent · Copyright · Comparative law · EU law · Exhaustion · Digital content

\section{Introduction}

Copyright literature is often critical of its success in balancing interests for digital uses of copyright works in reality. ${ }^{1}$ Some argue that legislation and jurisprudence

1 Geiger et al. (2017), p. 34; Westkamp (2017), p. 4; Sganga et al. (2015).

G. Jenkins $(\bowtie)$

PhD Candidate; Herchel Smith Scholar, Centre for Commercial Law Studies, Queen Mary

University of London, London, United Kingdom

e-mail: g.jenkins@qmul.ac.uk 
implicitly require EU Member States to exercise caution as digital use is considered to threaten copyright holders' desired business models. ${ }^{2}$ In Tom Kabinet ${ }^{3}$ the Court of Justice of the European Union (CJEU) recently confirmed this cautionary approach and ruled against business models which bolster users by providing the resale of downloadable copies. The case involved a collective management organisation for Dutch publishers who brought a copyright infringement action against Tom Kabinet, a supplier of used e-books, in the Netherlands. The case was referred to the CJEU as the referring court was unclear whether supplying e-books through a membership system contravened the copyright distribution right, and if it did, whether it may be exhausted pursuant to the Information Society Directive. If this interpretation were correct, it was queried whether copyright holders could then object to any reproductions following a digital resale which are necessary for the lawful transmission between subsequent purchasers.

While the CJEU adhered strictly to the wording of the Information Society Directive and the WIPO Copyright Treaties, the judgment failed to distil any clear criteria to balance rights regulating digital ownership and access. Indeed, the Advocate General simply outlined various arguments against and for the extension of exhaustion to downloadable copies and stated that the advent of new business models such as streaming means that the concept of digital exhaustion is redundant. ${ }^{4}$ The result was lacking legal certainty as users saw their rights of access further eroded without proper evaluation. This article finds this conservative response harrowing, particularly when considering the overarching normative argument in copyright jurisprudence and theory that a balance should be struck between copyright holders and users. ${ }^{5}$ While context is important when balancing interests, a clear set of criteria for balancing interests of access in the digital environment is left wanting. This article considers whether implied consent can fill this legal lacuna by relying on its status as a fundamental legal principle of both common law and civil law and argues that it can provide a more flexible and holistic approach to digital EU copyright law.

The article begins by first reviewing barriers to users' access to digital content and suggests that an extended doctrine of implied consent could flexibly respond to them in a reasonable and proportionate manner. The article subsequently traces the proposed doctrine's foundations in the concept of an implied licence through both the contractual interpretation of implied consent and the principle of copyright authorisation. ${ }^{6}$ This analysis is across several jurisdictions, namely the United Kingdom (UK), the European Union (EU), Germany, the United States (US) and

\footnotetext{
${ }^{2}$ Ibid.

${ }^{3}$ C-263/18 Nederlands Uitgeversverbond and Others $v$. Tom Kabinet Internet and Others EU:C:2019:1111.

${ }^{4}$ C-263/18 Nederlands Uitgeversverbond and Others $v$. Tom Kabinet Internet and Others EU:C:2019:697 para. 95. Including the inability of the doctrine of exhaustion to achieve this balance.

5 Hua (2014), p. 66.

${ }^{6}$ Clearsprings Management Ltd v. Businesslinx Ltd [2005] EWHC 1485 (Ch). C-466/12 Nils Svensson and Others v. Retriever Sverige AB EU:C:2014:76.
} 
Australia, and asserts that the interface between both concepts form a fundamental legal principle, an extended doctrine of implied consent. It will also be important to consider whether the proposed doctrine would ultimately need to overcome similar challenges relating to the doctrine of exhaustion and its application to digital copies. Lastly, the practical contours the extended doctrine of implied consent will be drawn by applying the fundamental legal principle against an example illustrating users' access and interaction with digital content.

\section{Copyright and Access to Digital Content}

The concept of access sits at the core of copyright law. It is seen through the insertion of either specifically structured exceptions and/or limitations in most countries, and the creation of the more flexible fair use exception in the US. However, access to digital content is also a double-edged sword, as copyright predominantly focuses on the presence of authorisation by the holder by allowing authors to enjoy the exclusive right to authorise or prohibit any of the four economic rights of copyright, and in particular the distribution and communication right. ${ }^{7}$ The development of both these rights in relation to accessing digital content has been the source of much debate in the literature.

Users now live in a world where ownership merely extends to tangible property. They have effectively been licensed out of a choice. Despite the term "buy now" being plastered over all digital streaming services, users are in reality agreeing to conditional and impermanent access to digital content which some scholars have deemed as the "end of ownership". ${ }^{8}$ Indeed, the literature remarks in the context of digital copies, that despite the simplicity in naming such transactions, determining whether a user actually owns a copy is becoming increasingly more difficult. ${ }^{9}$ As licences become more complex and technological lock-in becomes the norm, suddenly users are confronted with an "all or nothing" approach in consuming and interacting with digital content. Unfortunately, most users accept this as the current digital state of play.

While outside the scope of this article, jurisdictions such as the EU have taken legislative steps to balance access to digital content. Measures including the Portability Regulation and Geo-blocking Regulation are all examples of positive law intended to ensure that the extent of access to digital content does not depend on the Member State one resides, but a blanket minimum standard. However, the success of these measures is questionable due to the complexity of copyright legislation and it is perhaps easier to carve out access in particular circumstances, much like the list of available exceptions and/or limitations. Consequently, despite

\footnotetext{
7 Art. 4(1) and Information Society Directive. Also see the Berne Convention of 1979 and the World Intellectual Property Organization (WIPO) Copyright Treat of 1996 which both provide that authors of copyright works shall enjoy the exclusive right of authorising related economic rights such as reproduction and communication.

8 Perzanowski and Schultz (2018), p. 6.

9 Chapdelaine (2018), p. 19.
} 
the rising significance of access for users, there fails to be adequate legal scaffolding to support real implementation.

This article submits, in lieu of further legislation, that courts build upon implied licences jurisprudence to explicitly respond to the clear imbalance of copyright interests relating to digital content. Referred to as an extended doctrine of implied consent, this proposed doctrine could be enlivened by courts in circumstances where the factors surrounding the subsequent use are deemed reasonable and appropriate. Before this article will illuminate the types of factors which could evidence a more flexible and holistic approach, the doctrinal foundation will be traced; namely, the interface of two forms of implied licenses in copyright jurisprudence: contractual interpretation and the principle of copyright authorisation.

\section{A Fundamental Legal Principle}

This article relies upon a broad definition of implied licences to include both the traditional method of contractual interpretation which is used to track contracting parties' unexpressed intent to supplement an agreement, ${ }^{10}$ and the principle of copyright authorisation. Commentary explains that implied licences were imported into copyright law to resolve two conflicts: first being the tension between private property and copyright ownership, and secondly, the relationship between the copyright owners and copyright transferees. ${ }^{11}$ This is best described by considering the tension between copyrights and copies, meaning that copyright ownership over an intangible creative work can, to some extent, conflict with copy ownership which "secures domain over the use and alienation of a concrete instantiation of the work". 12

Implied licences have been relied upon by courts to help relieve this tension. Courts have allowed reasonable use of copyright works despite the absence of explicit consent. ${ }^{13}$ So whether reasonable use is founded on the surrounding factual matrix of a contract for commissioned work silent on potential ownership of prospective copyright, ${ }^{14}$ or to ensure that consumers are able to reasonably use their personal property, ${ }^{15}$ it is a flexible tool that could have the potential to balance copyright interests in the digital environment. Indeed, commentary suggests that the implied license doctrine is experiencing a revival in the context of access to digital content, specifically regarding the issue of linking. ${ }^{16}$ Thus, it is pertinent to review the aptitude of implied licences in the digital environment, either through contractual interpretation or the principle of copyright authorisation, to determine

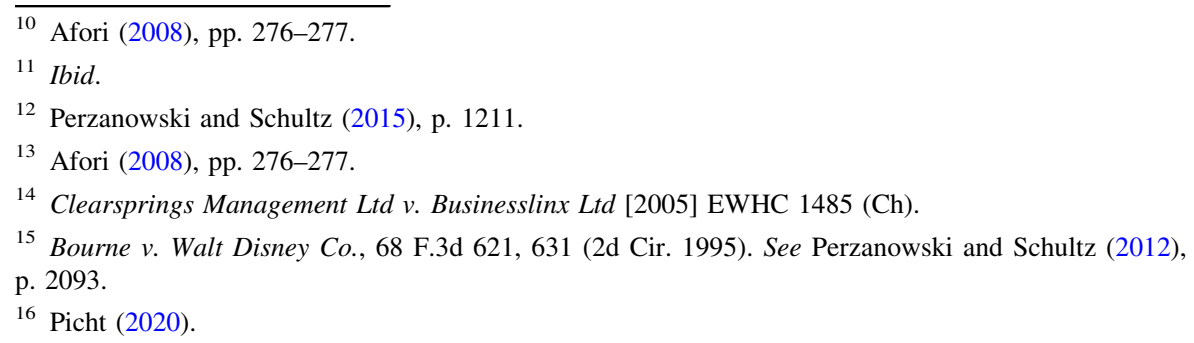


whether this interface between both is a fundamental legal principle capable of balancing all digital copyright interests.

\section{$3.1 \mathrm{UK}$}

In the UK, implied licences form part of a wider common law rule relating to the implication of terms. Common law courts are willing to infer certain terms when the contract is silent based on the conduct of the parties and the surrounding factual matrix. Traditionally, implied terms are implied in either law or fact, though a third circumstance can also result in an implied term, by custom or usage. ${ }^{17}$ While this is a peculiar judicial power as implied terms theoretically conflict with wellestablished common law principles such as freedom of contract and sanctity of contract, $^{18}$ implied terms also bolster the rights and protection of both parties. ${ }^{19}$ Commentary even reflects that "gap-filling is quite simply essential for contracting to work ... [as] it would be intolerable for the courts to declare contacts void simply because some unforeseen possibility had not been considered by the parties at the time of contracting, thus rendering the contract void for uncertainty." 20

Historically, the UK relies on several criteria including: that the term must be reasonable and equitable; it must be necessary to give business efficacy to the contract; it must be so obvious that "it goes without saying"; it must be capable of clear expression; and that it must not contradict any express term of the contract. ${ }^{21}$ This approach has been subject to much debate as in Attorney-General of Belize $v$. Belize Telecom Ltd the Privy Council widened the concept of contract construction to include implication. ${ }^{22}$ While this may seem merely of theoretical significance, the consequence was also vastly practical as now the courts must turn not to what the parties necessarily would have intended, but the meaning which the agreement conveys to a reasonable person who would have all the background knowledge which would be reasonably available to the audience to whom the instrument is addressed. $^{23}$ Thus, the implication of a term became more squarely focused on the construction of the legal instrument aided by the surrounding factual matrix from the perspective of the reasonable person.

However, implied terms were to experience more criticism, as the Supreme Court disagreed with the above approach in Marks \& Spencer v. BNP Paribas Securities Services Trust Co (Jersey) Ltd. ${ }^{24}$ Lord Neuberger stated that "construing the words

\footnotetext{
17 Mysoor (2018), p. 665.

18 Austen-Baker (2017).

19 Salisbury (2016), p. 59.

${ }^{20}$ Low and Loi (2009), p. 565-566.

21 See BP Refinery (Westernport) Pty Ltd v. Shire of Hastings (1977) 180 CLR 266, 283, Lord Simon of Glaisdale (speaking for the majority, which included Viscount Dilhorne and Lord Keith of Kinkel). Also see the landmark case The Moorcock (1889) 14. P.D. 64, 68 (Bowen L.J.). Liverpool City Council v. Irwin [1977] AC 239, 258 (Lord Cross), 266 (Lord Edmund-Davies).

221 [2009] UKPC 10, [2009] 1 W.L.R. 1988 paras. 16-27.

23 Ibid para. 16.

24 [2015] UKSC 72.
} 
used and implying additional words are different processes governed by different rules". ${ }^{25}$ The difference between contract construction and implication was that the former referred to the intention of the parties to resolve an ambiguity or inconsistency and that the latter deals with matters where the parties themselves have made no provision. The Supreme Court found that it is only after the express terms of a contract are construed can the question of additional implied terms be considered. $^{26}$ The result was that implying terms into a contract became more burdensome due to the more literal interpretation, evidencing a less interventionist interpretation of business-to-business agreements often referred to as a minimalist approach. $^{27}$

However, it is important to note that the contractual interpretation of implied licences varies from the principle of copyright authorisation being implied by courts. If the contours of equitable copyright ownership are examined, one can distil that an implied licence can only be granted if it is necessary, in line with the minimalist approach of the UK courts. ${ }^{28}$ The crux of this defence is whether the surrounding factual matrix can give rise to a lawful use of a copyright work. In addition to whether the licence is necessary, the court will consider the price paid and the intention of the parties which is limited to the joint contemplation of that parties at the date of contract. ${ }^{29}$ It is in this interface between implied licences and copyright authorisation that the solution can be demarcated.

In the IP context, UK courts initially interpreted implied consent where it was reasonable to assume that the patentee impliedly consented to undertake a variety of actions related to the product containing the IP. ${ }^{30}$ In the UK, the principle has been extended to ensure that repairs can be performed, and that contractors can rely on architectural plans to erect buildings. While these initial cases were founded on the necessity of implying terms, there is now a trend to base the test on the concept of reasonableness. $^{31}$

The question becomes, what is the position of users, particularly in the digital environment and IP? As stated earlier, terms can be implied in law or fact. Certainly, numerous consumer legislation standards are implied into business to consumer contracts to support consumers such as the implied warranty as to the quality, fitness for purpose, or performance of any product made by the licensee under the licence. ${ }^{32}$ Some commentary even suggests that terms implied through usage or custom could be helpful in strengthening users' access and consumption of

\footnotetext{
25 Ibid para. 27.

26 Ibid para. 28.

27 Booton (2011), p. 35.

28 Robin Ray v. Classic FM PLC[1998] FSR 622

29 Ibid.

${ }^{30}$ In Badische Anilin and Soda Fabrik v. Isler[1906] 1 Ch 605 (High Court), [1906] 2 Ch 443 The Court of Appeal addressed the fact that if a consumer purchases a patented article and uses it, they do not infringe because the law implies a license by the patentee to the purchaser to sell or deal with the article as they please, unless at the time of purchase the patentee imposed a condition.

31 Booton (2011), p. 33.

32 UK Sale of Goods Act 1979
} 
digital content. ${ }^{33}$ Further, they propose that the copyright owner could impliedly consent to such use given her conduct and the circumstances, naming it a consentbased implied license justified on policy. ${ }^{34}$

Indeed, the position of third parties and end users culminated recently when the High Court considered a case involving TuneIn Inc., a company providing hyperlinks to radio streams globally, including the UK, and major music labels Warner and Sony. ${ }^{35}$ Birss $\mathbf{J}$ focused on the presence of authorisation from the copyright holder to the internet radio stations, finding that TuneIn Inc. were liable for radio stations outside the UK, but not those already licensed in the UK. Questions remain as to whether the latter position can be overridden by website terms and conditions which will severely impact both third parties and end users. ${ }^{36}$ In the meantime, this article will continue to outline the boundaries of the interface between the contractual interpretation of implied licences of which consent can be a term and the principle of copyright authorisation with reference to CJEU jurisprudence.

\section{$3.2 \mathrm{EU}$}

CJEU case law is well versed on the issue of linking as a series of leading cases have determined criteria when a user does not require explicit copyright authorisation relating to the right to communicate to the public. This collection of cases has examined the term "new public" in light of works that are made accessible on the internet by the copyright holder and have subsequently been used without consent in the form of a hyperlink. The question that has plagued the CJEU is to what extent these subsequent uses are lawful as the copyright holder has to some extent already communicated them to the public by uploading them to the internet. There is a line of analysis evident in the case law that despite the copyright holder making these accessible on the internet, they did not envisage communicating them to the entire internet and should be able to control any subsequent uses of the works they did not envisage because this provides a new stream of income.

The leading case, Svensson, holds that linking can infringe copyright in certain circumstances, although not where the hyperlinks were to content that was lawfully made available without restriction in the first place. ${ }^{37}$ This case involved the supply of clickable links via a website to works protected by copyright. While this indeed was a communication to the public, it was not to a "new public" as the works had initially been made available without restriction. ${ }^{38}$ This article suggests that this

\footnotetext{
33 Mysoor (2018), p. 667.

34 Ibid.

35 Warner Music UK Ltd and Sony Music Entertainment UK Ltd v. TuneIn Inc. [2019] EWHC 2923 (Ch).

36 Indeed, in Meltwater saga, the CJEU held that end users do not need a licence for both cached and onscreen copies created by accessing the hyperlinks sent as part of a news aggregator service. See C-360/ 13 Public Relations Consultants Association Ltd v. Newspaper Licensing Agency Ltd and Others U:C:2014:1195. Note that this issue of contractual override will most likely be discussed on appeal.

37 C-466/12 Nils Svensson and Others v. Retriever Sverige AB EU:C:2014:76 paras. 25-28. Stokes (2019), p.173.

38 Svensson paras. 25-27.
} 
approach is comparable to an implied licence. It argues that as the CJEU focused on the surrounding facts of the initial communication by the copyright holder to conclude that as there is no new public, the copyright holder cannot object to subsequent linking. Conversely, if the copyright holder had used technical restrictions to ensure that the work was only communicated to a designated public, any subsequent linking would require copyright authorisation from the copyright holder. Thus, the absence of any technical restrictions is to an extent comparable to the implication of a licence to link the copyright work; termed simply, an implied copyright authorisation.

In GS Media, other factors were considered such as the presence of a profitmaking intention or knowledge (i.e. in this case the alleged infringer knew that the initial communication was unlicensed) in the subsequent communication. ${ }^{39}$ It followed, that the Svensson approach was limited as the CJEU held that such knowledge, which could be presumed from the presence of financial gain, ${ }^{40}$ was an aggravating factor and meant that the alleged infringer could not benefit from an implied copyright authorisation. Clearly such knowledge demonstrates an upper limit on the threshold for applying an implied copyright authorisation. However, the CJEU also confirmed that the financial-gain presumption was rebuttable $\mathrm{e}^{41}$. Thus, the case additionally demonstrated through the rebuttable presumption that when the court considers whether copyright authorisation was required for a communication to the public it is not a hold fast rule, but a facts-based approach dependent upon the character of the digital use.

EU jurisprudence has also witnessed further threshold limitations of the implied copyright authorisation approach in Renckhoff. ${ }^{42}$ In this case the CJEU distinguished hyperlinking and embedding from directly posting content online, meaning that the latter could not benefit from an implied copyright authorisation. The CJEU explained that there must be such a balance in the digital environment of the interests of copyright holders and the protection of the interests and fundamental rights of users of copyright works, such as their freedom of expression and information. However, in sum, the act of direct posting, in the view of the CJEU, did not respect the fair balance required in recitals 3 and 31 of the Information Society Directive.

This distinction between hyperlinking and direct posting partly rested on the fact that hyperlinks can be made obsolete by removing the work from the site it appears on which indicates that the copyright holder still retains some control over how the work is used. Further, the CJEU remarked that the public initially considered by the copyright holder was composed solely of potential visitors to the original website, not the whole internet as an audience. While this case restricts the boundaries of users' rights to access and share content, the case also evidences the significance of the initial authorisation of the copyright holder. One could even propose that the initial authorisation was based upon a set of facts in which the CJEU held that the

\footnotetext{
39 C-160/15 GS Media BV v. Sanoma Media Netherlands BV and Others EU:C:2016:644 paras. 51-55.

40 Ibid.

41 Ibid para. 51.

42 C-161/17 Land Nordrhein-Westfalen v. Dirk Renckhoff EU:C: 2018:634.
} 
copyright holder could not have authorised the subsequent communication, indicating a propensity of their analysis to align with implied licences analysis generally.

Indeed, this review of the communication to the public right has revealed some similarity to the contractual interpretation of implied consent. Firstly, the "new public" construct helps to define a fair balance between copyright interests as it has identified areas regarding access and sharing that should be better balanced and considered not to contravene copyright. Secondly, the CJEU's reliance upon the "smooth functioning of the internet" as a condition of copyright authorisation demonstrates a preparedness to balance the high protection of copyright holders against the necessity of allowing users to access and interact with copyright work in the digital environment. Thirdly, the presence of limitations to implied copyright authorisation has revealed a facts-based analysis whether it be knowledge that the initial communication was unlawful, the rebuttable financial-gain presumption, or the type of digital use such as direct posting.

Ultimately the "new public" is a rigid structure that is not likely to keep pace with new ways of consuming digital content, and the "smooth functioning of the internet" is an overly broad and ambiguous term with no objective meaning. While the implied copyright authorisation approach is comparable to the contractual interpretation of implied consent, a more helpful legal construction could be to build upon both experiences through the construction of an extended doctrine of implied consent. This is because there is no concrete CJEU case law dealing specifically with implied licenses for copyright works in the digital environment for end users. Definitely, in the only other linking case, BestWater, the CJEU failed to acknowledge the relevance of the developing implied license doctrine in digital EU copyright law. ${ }^{43}$ While commentary finds comparison in EU trade mark law where consent to exhaust the distribution right can be implied, this must be unequivocally demonstrated, ${ }^{44}$ indicating a more burdensome threshold for users in addition to their poor bargaining status in business to consumer contracts.

Thus, the picture has only become more complicated in the EU and this has only intensified with the introduction of the directive "on copyright in the Digital Single Market" (DSM Directive). The Directive focuses inter alia on the liability of intermediaries and requires them to regulate unauthorised copyright material made available online. This would undoubtedly include material which has been subject to hyperlinking which prima facie would most likely exclude any consideration of implied copyright authorisation.

\footnotetext{
43 Case C-348/13 BestWater International GmbH v. Michael Mebes and Stefan Potsch EU:C:2014:2315.

44 C-414/99 to C-416/99, Zino Davidoff SA v. A \& G Imports Ltd and Levi Strauss \& Co. and Others v. Tesco Stores Ltd and Others, Judgment of the Court of 20 November 2001. In trade mark law, implied consent can exhaust the distribution right but it is subject to the trade mark owner being able to object on the basis that there are other legitimate reasons such as the distinctiveness of the mark is threatened. See Art. 14(2) Trade Mark Directive.
} 


\subsection{Germany}

German jurisprudence has long addressed hyperlinking through one of the elements of an implied license, implied consent. ${ }^{45}$ Commentary suggests that the German approach is much broader than the common law countries, as consent includes both what was captured in the initial authorisation, as well as when copyright holders have failed to take positive steps to ensure that an activity remains prohibited. ${ }^{46}$ This position is exemplified by the Vorschaubilder cases which demonstrate the German Federal Supreme Court interpreting a standard of reasonableness in the digital environment by considering what steps the copyright holder could have taken to prevent hyperlinking. ${ }^{47}$ This reasonableness standard is interpreted through the lens of preserving hyperlinking as a fundamental use on the internet.

In Vorschaubilder I, the Court found that if an image is uploaded onto the internet without the copyright holder implementing any technical barriers, this equates to the copyright holder impliedly consenting to their reproduction by the alleged infringer. This was confirmed in Vorschaubilder II and the Court further explained that "an unlawful inference with a copyright protected right" can be allowed "on the grounds of a simple consent by the authorised party". 48 This position was grounded in the idea that as the copyright holder had consented to their images being displayed by thumbnails on Google images by other third parties, it was reasonable to conclude that given the nature of image search engines, the implied consent included images that were published on the internet without the copyright holder's permission. ${ }^{49}$

However, in two later decisions of the Berlin Regional Court, the implied consent argument was also partially restricted. ${ }^{50}$ The cases involve a global perfume manufacture and two internet intermediaries, Amazon and Google Shopping, that fell outside its selective distribution agreement. Those in the agreement could use photos assigned to the manufacturer by the photographer of some of its products. The selected distributors sold the products on various online shops using the photos, including Google Shopping and Amazon. Both intermediaries displayed the photo supplied by the selected distributors in an aggregated search result.

The distinction between the two is that Amazon also operates as a seller and uses the photos uploaded by other sellers. ${ }^{51}$ Both intermediaries attempted to rely on the implied consent defence to argue that they could use product images as they had already been communicated to the public in line with Vorschaubilder I and II.

\footnotetext{
$\overline{45}$ Westkamp et al. (2016), p. 39.

${ }^{46}$ Karapapa (2017), p.87. Note that some German courts have failed to interpret an implied license in linking and embedding scenarios, such as Roche Lexikon Medizin and Der Poet. See Pihlajainne 2012, p.5 for an overview.

47 German Federal Supreme Court, Judgment of 29 April 2010, I ZR 69/08, Vorschaubilder I. German Federal Supreme Court, Judgment of 19 October 2011, I ZR 140/10, Vorschaulbider II. German Federal Supreme Court, Judgment of 21 September 2017, I ZR 11/16 - Vorschaulbider III).

48 Chapdelaine (2017), p.789.

49 Ibid. See Stowel 2009, p. 87

502015 BeckRS 07179 and 2015 BeckRS 07175.

51 Bildhauser 2015, p. 709 for an overview in English of the decisions.
} 
However, the Court restricted implied consent to thumbnails optimised for only search engines. The fact that Amazon had its own economic interests in third-party products appearing on its platform as part of the service to dealers did not particularly strengthen their argument. ${ }^{52}$

Vorschaubilder III is the first application of CJEU case law on hyperlinking. The case involved photos accessible on an image search website. The copyright holder of the photos alleged that the photos were accessible via a password-protected area of their website and that the alleged infringer had allowed unauthorised photos to be uploaded illegally onto their freely accessible website. The German Federal Supreme Court held that the assumption founded in GS Media regarding knowledge of illegal content does not apply to search engines and to hyperlinks leading to a search engine.

The decision to limit the GS Media conditions and allow search engines to benefit from an implied licence despite evidence of some unlawful knowledge has been heavily criticised. ${ }^{53}$ The court's reasoning that such use shall be allowed to ensure the maintenance of the functionality of the internet has also been rejected by the literature. ${ }^{54}$ Commentary remarks that implied licences under these circumstances conflict with the principle that copyright holders must be explicit when assigning usage rights. ${ }^{55}$ These commentators claim that such licences create too much legal uncertainty as copyright holders are left to identify when uses of content "will be considered common enough to justify the assumption of implied consent". 56

\subsection{US}

Similarly to other common law jurisdictions, US courts generally focus on the parties' intention when implying terms under contract law. ${ }^{57}$ In relation to copyright authorisation in the US, an implied license is found if the following criteria are met: the licensee requested the creation of the work, the licensor made the work and delivered it to the licensee, and that the licensor intended that the licensee copy and distribute the work. ${ }^{58}$ Unfortunately, this construct does not consider the position of the end user.

However, in Field v. Google ${ }^{59}$ a district court considered facts that are more akin to end users. The court found that the copyright holder's knowledge of Google's

\footnotetext{
52 Ibid p. 711.

53 Heinzl (2020), p. 85. "Note that in this case the unlawful behaviour was on behalf of the persons uploading the unauthorized photos on to websites that were subsequently indexed by Google.

54 In particular, the Court emphasises the burden that search engines would encounter if required to check whether images automatically displayed were initially legally posted before listed as a thumbnail.

55 Höppner and Schaper (2016), p. 642. The authors compare this approach to the Robots Exclusion Protocol discussed in the US section of this article.

56 Ibid.

57 Quinn (2014), p. 1199; Kiker (2012), p 71

58 Asset Marketing Sys, Inc. v. Gagnon, 542 F.3d 748 (9th Cir. 2008); see also Numbers Licensing LLC v. bVisual USA Inc., 643 F. Supp. 2d 1245 (E.D. Wash. 2009) and Effects Associates, Inc. v. Cohen 908 F. 2d 555 ( $9^{\text {th }}$ Cir. 1990).

59 Field v. Google Inc., 412 F. Supp. 2d 1106 (D. Nev. 2006) (“Field").
} 
indexing activities and failure to use the Robot Exclusion Protocol contributed to the implication of an implied licence. ${ }^{60}$ The result was that a new two-part test was formed: firstly, the copyright holder must know of the use, and secondly, they must encourage it. ${ }^{61}$ Following Field, US courts have applied the two-part test, most notably in the Google Books Litigation. ${ }^{62}$ Commentary has characterised this decision as validating an opt-out system to copyright which is similar to the EU and German approach as both recast the passive failure to prevent caching or accessing content as an active behaviour to imply a licence or copyright authorisation. ${ }^{63}$

However, US courts have also distinguished the Field approach, ${ }^{64}$ finding that an implied licence could become too burdensome on copyright holders to prevent unauthorised access. In Associated Press, the courts opted for the alleged infringer to demonstrate lawful use as opposed to considering the implication of consent. ${ }^{65}$ The court reasoned that, in the interest of the openness on the internet, it should be limited to circumstances where there is a clear interest on behalf of the website to broadly limit access. ${ }^{66}$

This is because it is assumed that users prefer search engine crawlers to be able to visit as many websites as possible and to include these websites in their search results. The court concluded based on policy, that to allow this extension of the robot exclusion standard implied licence would require websites concerned about improper copying to signal to crawlers that they are not welcome. This position echoes criticism to the German implied licences approach as commentators remark that it is the equivalent of the failed Robots Exclusion Protocol, ${ }^{67}$ meaning that copyright holders would be left to identify uses of content that are common enough to justify the assumption of implied consent.

The literature clearly focuses on the position of search engines to impose "optout" measures upon copyright holders which will result in the user determining the scope and conditions of the lawful use of content. ${ }^{68}$ Other scholars argue that the Court in Associated Press incorrectly found that the Robots Exclusion Protocol optout system would be so undesirable because "having an opt-out system where it is assumed that all aggregators are entitled to scrape the Internet, unless the copyright holder opts out, will create a better balance". 69 Essentially, this argument asserts

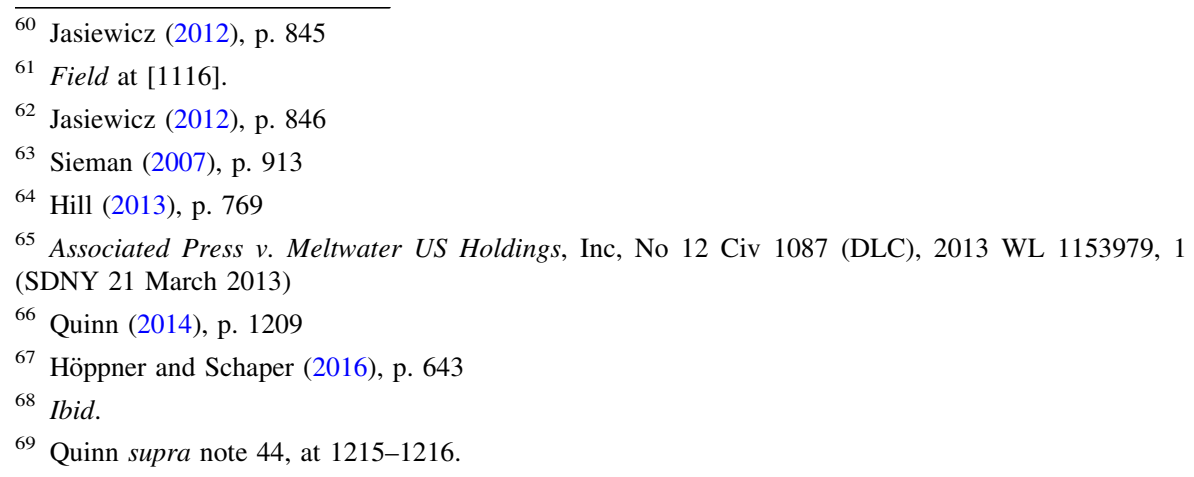


that "it will balance the benefits provided by news aggregators and the content providers' desire to single out select aggregators who are not benefiting them through increased consumer traffic". ${ }^{70}$

\subsection{Australia}

Australia also follows the common law approach set out above regarding implied licenses and the implication of terms. ${ }^{71}$ Recently, this was conveniently summarised in Hardingham v. RP Data Pty Ltd where the Federal Court of Australia reconfirmed the test for implication which builds upon UK case law. ${ }^{72}$ Additionally, Australian jurisprudence states that there must be a focus on reasonableness and effectiveness in the case of informal contracts, the implication must be drawn from objectively assessed relevant circumstances and that the onus of establishing infringement lies with the copyright holder which means that they bear the onus of establishing the absence of an implied licence. ${ }^{73}$

In Hardingham v. RP Data Pty Ltd the Australian Federal Court objectively considered the factual matrix of the initial agreement noting that despite explicit agreement, the alleged infringer was authorised to grant sub-licences allowing a separate entity to upload copyright works. Additionally, the fact that the copyright holder failed to end business relations with the infringer was an aggravating factor. While this case concerns the use of copyright works through the lens of contract interpretation, the approach taken by Australian courts is to an extent comparable to the EU. In both jurisdictions the courts rely on the surrounding factual matrix, particularly the presence of knowledge, to impute either an implied licence or copyright authorisation. $^{74}$

When considering linking, Australian jurisprudence builds upon the authorisation element in relation to intermediaries authorising copyright infringement. Case law indicates that copyright authorisation should be interpreted broadly, not requiring the existence of explicit or active consent. ${ }^{75}$ Section 101 of The Copyright Act 1968

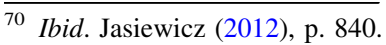

71 Note that there is a slight difference in term implication and contract construction when comparing the UK and Australia. See Edelman J 2016.

72 [2019] FCA 2075 ("Hardingham") at [45]-[46]. The case cites both landmark UK cases BP Refinery (Westernport) Pty Limited v. Hastings Shire Council (1977) 180 CLR 266 at 283 and Ray v. Classic FM Plc (1998) 41 IPR 235 at 248-249.

73 Hardingham at [48]-[50]. Note that the onus is discharged if the alleged infringer raises a positive assertion that an implied licence of a certain scope exists. See Acohs Pty Ltd v. Ucorp Pty Ltd (2012) 201 FCR 173.

74 Australian courts are prepared to be slightly more activist, implying from the nature of a specific industry and relevant actions. Indeed, one could consider the implications of hearing this case in either the EU or US, whether the focus would be on the fundamental need for agencies to be able to upload real estate materials to the relevant platforms as part of the functioning of the digital environment, as opposed to the strictly commercial perspective the Australian court adopts.

75 University of New South Wales v. Moorhouse (1975) 133 CLR 1. Note Gibbs J's separate judgement: "The word authorize connotes a mental element and it could not be inferred a person had, by mere inactivity, authorized something to be done if he neither knew or had reason to suspect that the act might be done" at para. 200 .
} 
states that it is unlawful for a person other than the copyright holder or without a license to authorise any act comprised in the copyright. Authorisation is determined by considering the extent of the infringer's power to prevent the infringement, the nature of any existing relationship between the person and the act concerned, and whether the person took reasonable steps to prevent or avoid the act. ${ }^{76}$ These conditions are not exhaustive, ${ }^{77}$ and some commentary suggests that they are relied upon to find authorisation when the "authorising defendant cannot control the end user." ${ }^{78}$ Indeed, this has resulted in a varying degree of uncertainty in Australia of what authorisation actually means in practice. ${ }^{79}$

The leading case Cooper v. Universal Music Australia relates to a website that linked website visitors to infringing MP3 files on third-party websites. ${ }^{80}$ The Full Federal Court of Australia found that the host of the website had the power to prevent copyright infringement as it was possible to both remove infringing links from the website and take reasonable steps to inquire whether the linked content was infringing. The Court also took stock of the commercial interest the host had in attracting users and found that they had a relationship with direct infringers. It was clear that the control Cooper had in creating and maintaining the website of infringing links played a dominant role in the alleged infringer's liability. If this is compared to peer-to-peer sharing cases in Australia, one finds that the threshold test for authorisation is quite high as despite having less control than Cooper over the unlawful behaviour of end users, these intermediaries are still found liable. ${ }^{81}$

While Australian jurisprudence on authorisation is from the perspective of the alleged infringer, there is still a degree of convergence with the approach of the EU as there is a causal link between taking reasonable or effective precautions against copyright infringement. In Svensson, this was the requirement that copyright holders use technical restrictions to ensure that they can enforce their exclusive communication right in the future. Indeed, both Germany and the US are grappling with the same question albeit with differing solutions: who should hold the burden of proof, the copyright holder, or the copyright user? In Australia, perhaps one can point to the commercial nature of the cases that have been heard so far and the clear absence of search engines or end-user fact patterns which have dominated recent jurisprudence in the EU and US. If this changes, Australian courts may begin to approach questions of authorisation and implied licences through the lens of maintaining the functioning of the digital environment.

\footnotetext{
$\overline{76}$ Copyright Act 1968 (Cth) Sec. 101(1)(A).

77 Universal Music Australia Pty Ltd v. Cooper (2005) 150 FCR 1 at [81].

78 Strowel (2009), 125.

79 Pappalardo and Suzor (2018), p. 483.

80 [2006] FCAFC 187 ("Cooper").

81 Pappalardo and Suzor (2018), p. 484. See Universal Music Australia Pty Ltd v. Sharman License Holdings Ltd (2005) 222 FCR 465.
} 


\subsection{Conclusion}

This article submits that reliance upon implied licences to regulate digital use of copyright works is a well-established principle: whether through the lens of contractual interpretation or the implied copyright authorisation approach, the doctrine is used in varying formats and extents to regulate the use of copyright works in the UK, the EU, Germany, the US and Australia. In all these jurisdictions, courts attempt to strike an appropriate and reasonable balance between users being able to access and consume copyright works on the one hand and incentivising and supporting the digital content markets on the other. These responses evidence the foundations of a relatively flexible framework which can be expanded upon to meet the challenging boundaries of the digital environment.

It is from this foundation that this article submits that an extended doctrine of implied consent can emerge as a fundamental legal principle. The attraction of this solution is clear: as commentary explains, a broader, open standard that is distinct from the implied licence's contractual restrictions would allow the judiciary to "infuse reasonableness" into copyright conflicts. ${ }^{82}$ This approach is described by the commentary as ensuring the "reasonable use of works in the digital environment", particularly "linking and framing, the operation of search engines and the sale of works through transmission of their digital copy," areas where implied licenses have failed. ${ }^{83}$ Thus, the true open nature of implied consent means that there is no need to track the intent of the copyright owner, ${ }^{84}$ allowing reasonable uses by end users of works within the digital environment to be considered lawful.

While US commentary grounds an open standard of implied consent in the tradition of copyright jurisprudence to include flexibilities such as the fair use doctrine and first sale, this article contends that a more grounded approach could be utilised in the EU and $\mathrm{UK}^{85}$ As discussed earlier, in the common law there are several justifications for term implication, such as that "the term captures the normal incidences necessarily found in a particular type of contract." ${ }^{86}$ These terms are not implied to capture the unexpressed joint intention of the parties, but because a court is attempting to achieve policy objectives such as fairness or efficiency. ${ }^{87}$ This concept of reasonableness is mirrored in other sources of EU and UK law from equity, to competition law, and even, consumer law with the result being that certain standards whether statutory or precedent, can override the contractual intention of the parties of the contract.

\footnotetext{
82 Afori (2008), p. 278. Also see, Guibault et al. (2016), p. 438. These restrictions could include the court's adherence to contract construction, unequal bargaining positions (particularly between end-users and copyright holders), and the ability to contractually override some exceptions and limitation.

83 Afori p. 276.

84 Afori p. 277.

85 Ibid.

86 Mysoor (2018), p. 666.

87 Ibid. Mysoor also explains that these terms are usually confirmed in statute such as the Sales of Goods Act in the UK. This justification also strikes at the heart of implied license discussed earlier.
} 
If the extended doctrine of implied consent is established, the resolution of these conflicts can be achieved through a non-contractual method, perhaps similar to the tortious origins of copyright generally, ${ }^{88}$ which promotes policy considerations such as the free movement of goods, consumer protection and the restraint of monopolies. ${ }^{89}$ The significance of policy in copyright is most obvious today, as the bundle of exclusive rights granted to copyright holders continues to expand in the digital environment and conflicts between jurisprudence and socially accepted practices increase. ${ }^{90}$ Commentary also explains that copyright is indeed at a crossroads as "everyday activities ... depend on the potentially fickle toleration of copyright owners." 91 Thus, an extended doctrine of implied consent potentially holds the tools to mediate copyright holders and users in a more reasonable manner in the digital environment.

One must also be wary of potential challenges to such a digital mediator as the CJEU commented, in obiter, in Renckhoff that if Svensson (the implied copyright authorisation approach) was followed on these facts, it would also amount to establishing a principle of exhaustion applicable to the right to communicate to the public. This is particularly pertinent as the application of the doctrine of exhaustion to digital formats is uncertain. Thus, this article will now assess the extent to which it could impact on an extended doctrine of implied consent.

\section{Doctrine of Exhaustion}

The doctrine of exhaustion refers to the basic principle that once a good has transferred ownership, the right holder's ability to distribute or control its distribution disappears. Art. 4(2) Information Society Directive explains that the distribution right can be exhausted following the first sale or other transfer of ownership in the Community of that object made either by the rightholder or with his consent. Prima facie, it is important to note that the Art. 4(2) restricts exhaustion to "objects". This is controversial because UsedSoft confirmed the application of the doctrine of exhaustion relating to used software. ${ }^{92}$ So long as certain conditions are met, ${ }^{93}$ the copyright holder's distribution right is exhausted under Art. 4(2) of the Software Directive.

\footnotetext{
${ }^{88}$ Note that this a is a trend occurring in relation to intermediaries, as jurisdictions such as the EU introduce tortious duties of care to respond to issues of "digital trespass". See the DSM Directive and See Kylie Pappalardo, "A tort law framework for copyright authorisation," (DPhil thesis, Queensland University of Technology 2016) at 256 for a comprehensive overview of the utilising tort law to limit copyright liability for intermediaries and its impact on end users in Australia. In the EU, this is evidenced by the reintroduction of fundamental rights analysis within copyright exceptions and the doctrine of exhaustion generally, emphasising the role of proportionality.

89 Afori (2008), p. 291.

90 Guibault et al. (2016), p. 439.

91 Ibid.

92 C-128/11 UsedSoft GmbH v. Oracle Inernational Corp. EU:C: 2012:407.

93 It must relate to the sale a copy of software. This means that the transaction must include a right to use that copy for an unlimited period in return of a payment for a fee.
} 
When deciding whether permanent downloadable copies, such as an "online reading club" that allowed private users to sell and purchase lawfully acquired DRM-free, used e-books via a private platform, ${ }^{94}$ are captured by the distribution right, the CJEU in Tom Kabinet strictly adhered to the wording of the World Intellectual Property Organization (WIPO) Copyright Treaty (WCT). Article 6 of the WCT defines the right of distribution as requiring WTO member states to ensure that authors of literary and artistic works enjoy the exclusive right of authorising the making available to the public of the original and copies of their works through sale or other transfer of ownership. ${ }^{95}$ The CJEU confirmed that the WCT Agreed Statement clarifies that "copies" and "original and copies" refers to "fixed copies" that can be put into circulation as tangible objects." 96 This is reflected in recitals 28 and 29 of the Information Society Directive which state that a use which is not connected to a tangible copy, or those that are offered as a service, cannot exhaust a right holder's exclusive rights. ${ }^{97}$

Then the CJEU distinguished e-books from used software, which was captured by the distribution right and exhausted in UsedSoft, in terms of fact and law. Firstly, the Court characterised the Software Directive as lex specialis which limited the exhaustion doctrine to software. ${ }^{98}$ Secondly, they relied on Nintendo to assert that exploitations such as e-books are not covered by the Software Directive as despite being a complex product, the software is merely incidental in relation to the work contained in the e-book. ${ }^{99}$ It was clear from the CJEU's perspective, that the Information Society Directive, despite parallels with the Software Directive, was never intended to allow permanent downloadable copies to firstly be captured by the distribution right, and secondly, for them to be subject to the doctrine of exhaustion. While some commentary contends that the CJEU in Tom Kabinet either "purposely construed the law to arrive at this outcome, or made a mistake when it disregarded the relevant Agreed Statement of the WCT, ${ }^{100}$ the result was in, the distribution right is not applicable to digital content, and neither exhaustion pursuant to Art. 4(2) Information Society Directive.

While Art \& Allposters predates Tom Kabinet, it is significant in this discussion because its analysis of transferring ownership of content indirectly reflects the "new public" discourse preferred by the CJEU. ${ }^{101}$ While the case does not directly

\footnotetext{
94 Ghosh and Mezei (2020), p. 251.

95 World Intellectual Property Organization (WIPO) WIPO Copyright Treaty adopted by the Diplomatic Conference on December 20, 1996.

96 Tom Kabinet para. 40.

97 Ibid para. 51.

98 Ibid para. 55.

99 Ibid para. 59. C-355/12 Nintendo and Others EU:C:2014:25 para. 23.

100 Ghosh and Mezei (2020), p. 262-3. The Agreed Statement to Arts. 6 and 7 WCT states that the expressions "copies" and "original and copies", being subject to the right of distribution and the right of rental under the said Articles, refer exclusively to fixed copies that can be put into circulation as tangible objects. Ghosh and Mezei suggest that it is misleading to characterize the Software Directive as lex specialis on the basis that the Directive was introduced before the WCT was accepted with the effect that the EU law sustains special regulation on the resale of intangible copies of computer programs.

101 C-419/13Art \& Allposters International BV v. Stichting Pictoright EU:C:2015:27 (“Allposters”).
} 
consider the application of the doctrine of exhaustion to digital content, commentary reflects that the decision clarified the scope of the exhaustion principle relating to the transformation of a physical medium of a work. ${ }^{102}$ The CJEU held that the exhaustion principle is tied to a physical medium which commentary has remarked leaves no room for exhaustion of digital content pursuant to the Information Society Directive. Thus, the CJEU's historical approach indirectly prevented the possibility of transferring ownership of digital content falling under the Directive, such as e-books, digital music files, videos and even video games, without the "new" consent of the copyright holder, making a secondary market almost impossible in practice. $^{103}$

However, there are clear parallels between the CJEU's interpretation of the doctrine of exhaustion and the implied copyright authorisation construct. As, in the view of the CJEU, copyright holders should be able to capitalise on the new transformation that they have not yet contemplated and receive the appropriate reward for this new commercial exploitation of their work. ${ }^{104}$ Indeed, some commentators remark that the outcome of this approach is simply an alternate formulation of exhaustion: the loss of control of the use of the subject matter after the first lawful use by the rightsholder. ${ }^{105}$ Thus one can extrapolate that the doctrine of exhaustion and a communication made to the new public are to an extent, two sides of the same coin. It follows that, whether consent is required for every new transformation, new public, or resale, should become the central focus of modern EU copyright law in the digital age. The question becomes what should consent comprise: is it simply the act of initially putting the copy into circulation, or is it more nuanced, requiring specific consent to certain actions? This paper submits that the doctrinal origins of the exhaustion doctrine in primary EU law could be helpful in answering this question.

The first application of the doctrine of exhaustion in the EU relating to copyright was Deutsche Grammophon. ${ }^{106}$ The case related to the resale of records in Germany that were originally purchased in France at a lower rate. While Deutsche Grammophon argued that this contravened their right to distribute copyright works, the Court held that the distribution right was exhausted as the records were sold in France with their permission. The ECJ found that if the distribution right was not exhausted on these facts it would conflict with the EC Treaty (now TFEU) objectives including the prohibition of partitioning of the market, free movement of goods, as well as the prohibition of distortions of competition in the common market. ${ }^{107}$ The Court emphasised that if such a restriction were lawful it would be "repugnant to the essential purpose of the Treaty, which is to unite national markets into a single market." 108

\footnotetext{
102 Savič (2015), p. 389; Rosati (2015), pp. 677-678; Hojnik (2017), p. 77.

103 Westkamp (2007), p. 327.

104 Allposters para. 48.

105 Ghosh and Mezei (2020), p. 272.

106 Case C-78/70 Deutsche Grammophon Gesellschaft Gmbh v. Metro-SB-Großmärkte GmbH \& Co. KG. [1971] ECR I-499 ("Deutche Grammophon").

107 Treaty on the Functioning of the European Union. Mezei (2015), p. 27.

108 Deutsche Grammphon para. 12.
} 
However, the characterisation of the conflict between national IP rights and wider normative aspirations of an internal market would prove difficult to resolve. While today it is authority that in such a conflict, the exercise of IP rights may be restricted in so far as the specific subject-matter of the relevant IP right is safeguarded, ${ }^{109}$ commentary explains that previously IP owners benefited from the freedoms enshrined in the EC Treaty (now TFEU) and additionally, un-harmonised national IP legislation which also partitioned the market. ${ }^{110}$ Further, to avoid indicating a preference for the protection of IP rights or curbing IP rights without violating the EC Treaty, the CJEU relied on the exhaustion principle. ${ }^{111}$ The threshold for finding exhaustion in these specific cases was consent, and the ECJ construed it broadly, equating it with entering into a licensing agreement, including compulsory licences. ${ }^{112}$ Indeed, commentary remarks that "consent constituted the principle aspect for resolving and guiding the proportionality test - mostly, but not necessarily in favour of free circulation." 113

In Centrafarm, the ECJ held that patent owners cannot forbid the import of a protected product marketed in another Member State by him or with his consent as the restriction in trade that results is not necessary for him to enjoy the exclusive rights deriving from the parallel patents. ${ }^{114}$ In Merck, the ECJ reflected on the significance of the free movement of goods, confirming that it is a fundamental principle forming part of the legal and economic circumstances which must be taken into account by the patent owner when determining how he will exercise his exclusive right. ${ }^{115}$ The substance of this right was defined in Merck v. Primecrown as the exclusive right to put the invention on the market for the first time. Further, in Musik-Vertrieb Membran, the ECJ explained that there could be no additional royalties for a collecting society. The case confirmed the approach of the above cases, as the ECJ emphasised the following:

... in a common market distinguished by free movement of goods and freedom to provide services, an author ... is free to choose the place ... in which to put his work into circulation. He may make that choice according to his best interests, which involve not only the level of remuneration provided in the Member State ... but ... the opportunities for distributing his work and the marketing facilities which are further enhanced by virtue of the free movement of goods ... In those circumstances, a copyright management society may not be permitted to claim, on the importation of sounds recording into another

\footnotetext{
109 Jütte (2017), pp. 137-138.

110 Westkamp and Rosén (2012), p. 44.

111 Westkamp and Rosén (2012), p. 44. Westkamp notes that it also became irrelevant whether the agreement contained anti-competitive restrictions captured under Art. 101 TFEU (formally Art. 28 EC) which would necessarily supersede any right to prevent parallel imports.

112 Ibid.

113 Ibid p. 45.

114 C-15/74 Centrafarm BV and Adriaan de Peijper v. Sterling Drug Inc. EU:C: 1974:114.

115 C-267 and 268/95, Merck \& Co. v. Primecrown Ltd.
} 
Member State, payment of additional fees based on the difference in the rates of remuneration existing in the various Member States. ${ }^{116}$

This is quite an activist approach to balancing un-harmonised national IP legislation with the aims of the internal market. Indeed, commentary remarks that "it became clear that every act of putting a product into circulation resulted in exhaustion, even when the place of first circulation was a country in which no rights existed or where the owner could not be rewarded." 117 Evidently, the ECJ was focusing on the status of consent to reflect not only the impact of an IP holder placing a protected product on the market, but also the benefits that they receive in being able to do so in an internal market. Thus, the decision to put a protected product on the market could broadly be interpreted as the IP rights holder losing control of any subsequent use of the subject matter. ${ }^{118}$

Despite the CJEU narrowing the application of exhaustion to digital content pursuant to the Information Society Directive, there are clearly wider normative questions remaining. These include the application of primary EU law to digital content copies and whether denying the exhaustion of digital copies could contravene competition law. If so, there is potential that this construct could successfully balance copyright interests in the digital environment. Indeed reliance upon an extended doctrine of implied consent could ensure that reasonable and proportionate factors are taken into account. However, currently there is a low likelihood that this interpretation will be preferred as demonstrated by both the CJEU in Tom Kabinet, and the clear absence of the application of exhaustion to the digital environment through legislation.

As discussed in the previous section, ${ }^{119}$ it is clear that in several jurisdictions there is a strong reliance on solving these copyright conflicts through some form of an implied licence, either founded in contractual interpretation or what this article has termed an "implied copyright authorisation", which takes the form of the "new public" criterion in the EU. This propensity to focus on the matrix of facts available relating to the parties' intentions and conduct, or the initial communication of the digital content is very similar to the primary EU law origins of the doctrine of exhaustion and its treatment of consent. Thus, this article will now demarcate the boundaries of an extended doctrine of implied consent by drawing upon its status as a fundamental legal principle and additionally, the broad interpretation of consent in early exhaustion cases, to determine whether it can successfully mediate between copyright holders and users in the digital environment, specifically regarding their access to digital content.

\footnotetext{
116 C- Musik-Vertrieb membran GmbH and K-tel International v. GEMA EU:C:1981:10 para. 25.

117 Westkamp (2012), p. 44

118 This is only rebuttable in trade mark law where the IP rights holder can prevent exhaustion if the origin function of the trade mark is affected.

119 "3. A fundamental legal principle".
} 


\section{An Extended Doctrine of Implied Consent}

This article will now discuss the application of the extended doctrine of implied consent to an example illustrating users' access and interaction with digital content. ${ }^{120}$ The discussion that follows will focus on variables to the example which demonstrate thresholds of the extended doctrine.

Example A user makes a one-off payment to download a digital video game from a video game publishing company. The user must agree to the terms and conditions of the software publishing game's digital platform which facilitates the video game. The platform licence contains a clause that prohibits the person from reselling the access and use rights to the video game. A few months later, the user shares the downloadable copy of the digital video game with a friend, who in turn pays her a percentage of the initial one-off payment.

The crux of this example is whether the video game publishing company can restrict a subsequent use of the permanent downloadable copy post sale. The analysis of this question is two-pronged: is copyright infringed by the user sharing the downloadable copy to a friend, and what are the implications of the video game publishing company restricting a subsequent use through a contractual clause.

As this article has already explained, Tom Kabinet is authority that the distribution right, pursuant to the Information Society Directive, is not applicable to digital content copies, in deep contrast to the Software Directive, meaning that this right cannot be exhausted to allow resale of such copies. Thus, according to Tom Kabinet, the communication right is the applicable economic right, and involves two cumulative criteria: the act of communication (i.e. the provision of the downloadable copy), and that the work was made available to the public. While the user has shared the downloadable copy with one other person, the question is whether this was an indeterminate number of potential recipients. ${ }^{121}$

This article submits that one person would not qualify, but remember that successive recipients of contents form a public as well, such as potential recipients. ${ }^{122}$ Thus if one actual recipient and any other successive recipients qualify, the next step is whether the initial download from the video game publishing company to the user was communicated using specific technical means. From the outset, it is likely that the necessity of requiring access and use details to the video game publishing company's platform conforms with the concept of a technical device as without it, the user would not be able to play the video game and access the work.

If not, one must ask whether the user communicated the copy to a new public, that is one that was not already taken into account by the video game publishing company when they authorised the initial communication of the video game to the

\footnotetext{
${ }^{120}$ Note that as a first step in demarcating the boundaries of the extended doctrine of implied consent, this example focuses on experience of end users. The second step would be to consider its application to other types of users, namely internet intermediaries.

121 Tom Kabinet para. 66.

122 Ghosh and Mezei (2020), p. 256.
} 
public. In line with the propensity of the CJEU to interpret the communication right broadly, ${ }^{123}$ one can assume the case will be made that the video game publishing company did not intend to make the video game via downloadable copy available to a used video game market for a percentage of the normal cost of accessing the digital video game.

It is clear that the user infringed copyright in the video game by reselling it to a friend unless any exceptions or limitations apply, and thus, breached the platform licence's terms and conditions. ${ }^{124}$ This is an odd outcome for video game users and enthusiasts, especially if you grew up frequenting second-hand video game stores where users could resell physical data carriers that contained the video game. While there are certainly arguments supporting the denial of resale of downloadable copies in copyright law, these arguments should not be disproportionately applied to a downloadable copy on the basis of it being a computer program or a digital content copy which runs via software.

There is clearly an imbalance in the way physical data carriers containing video games and digital video games stored in downloadable copies are treated by copyright law. It is not surprising, as what is to stop the user from reselling their downloadable copy to more than one buyer, which in turn creates an infinite number of downstream copies. Even if the user does render their own copy unusable, it is commonly accepted that no file is ever truly deleted. For users, this is difficult to comprehend, particularly as industries such as video games, are increasingly only accessible via digital interaction. Users are expected to agree to such terms, or simply not access and enjoy video games, and this is not even addressing the onerous terms and conditions existing within end-user licensing agreements (EULAs).

An extended doctrine of implied consent could avoid this superficial distinction entirely, and provide a consistent legal concept for subsequent uses of digital content by users. It could build upon the implied licences and linking cases in the EU, to hold that in order to balance the interests of copyright holders and users digitally, it is reasonable and proportionate for EU copyright law to imply consent for subsequent uses of digital content copies in some contexts.

Both, Svensson and Renckhoff provide a helpful distinction as to when a subsequent use should be authorised through implied consent. Instead of focusing on the initial communication, the court could consider the impact of the subsequent use on the balance of copyright interests. In Svensson the nature of hyperlinking was considered not only a necessary requirement for the functioning of the internet, but temporary, in that the site where the work was displayed online could always be deleted. Conversely, in Renckhoff, the nature of the direct posting was permanent and would be more difficult to control as a copyright holder. Though perhaps in the latter case, the facts of the subsequent use could also lead to a different outcome if

\footnotetext{
123 Ibid p. 255.

124 Even if the remarks made by this article in relation to the application of exhaustion, either pursuant to Art. 4(2) Information Society Directive or through competition law ring true, the probability of this occurring are low without legislative oversight.
} 
consent were implied through the proposed doctrine, such as educational context and the lacking commercial intent of the subsequent use.

The extended doctrine of implied consent could also be bolstered by the broad treatment of consent in the earlier exhaustion cases. Indeed, the extended doctrine could be construed to capture the impact of copyright holders initially making the video game available to the public within a Member State of the internal market. Thus, it follows that as copyright holders benefit from both the freedoms enshrined in the TFEU and national copyright frameworks, there is an argument that they cannot also concurrently partition the digital single market. ${ }^{125}$

The question remains, however, what are the parameters of an extended doctrine of implied consent. This is best illustrated by referring to variables of the example above. Firstly, regarding the digital copy of the video game the user initially downloaded, if the user rendered this copy unusable, would this be a relevant factor in allowing the resale of the copy as a subsequent use? As discussed earlier, it is a fact universally acknowledged that no copy is ever truly deleted. But, what about the application of forward and delete technology? If there was certification that the seller could not access or sell the digital copy to other buyers following resale, this could be a pertinent factor in enlivening the extended doctrine of implied consent to allow the resale.

Indeed, as this example illustrates, the focus of the doctrine is on the impact of the subsequent use by the user, and the extent to which it balances copyright interests in the digital environment. The next question is whether the format of access is relevant. What if the user had a subscription to a video-on-demand (VOD) subscription service? The user pays a monthly fee in return for access to videos that they can consume according to their own schedule. Instead of the user reselling access to a permanent digital copy, the user gives their access details to a friend, who in return, gives them access details of a different VOD subscription service. The VOD licensing agreement includes the clause that users must not share their access details to the service. While this is clearly a breach of contract and an infringement under EU copyright legislation, ${ }^{126}$ the extended doctrine of implied consent would take into consideration the factors surrounding the sharing of access details.

If the user simply resold their VOD access details, it could lead to many users offering subscriptions at reduced prices meaning that there would be no incentive for users to purchase it at the normal subscription price. However, in this example, the subsequent use is not a resale, but password sharing amongst friends. While there is no doubt that this a contractual breach, if the extent of the sharing is limited or capped, this could be a reasonable subsequent use and one where consent could be implied. In reality, many VOD subscription services allow multiple profiles for users which facilitates sharing; however, these profiles are capped and often the user must pay a premium. Indeed, some VOD subscription services restrict sharing

\footnotetext{
125 Westkamp et al. (2016), p. 44. See Pihlajarinne (2012), for a comprehensive overview of the Geoblocking Regulation and whether it has responded to barriers to cross-border B2C transactions in the EU from the perspective of competition law.

126 If not an infringement of the communication right, it could infringe Art. 6 Information Society Directive relating to the circumvention of technological protection measures (TPMs).
} 
further, stating that it must only occur within the user's household. If users do "over-share" their details, VOD subscription services may not sue users, but they use technological protection measures (TPMs) to make this use more difficult in the future. This is usually achieved by regular confirmation of users' identity through requiring uses to constantly re-sign into all devices, as well as regular password resetting.

These types of restrictions on sharing access details are not founded in copyright law but are contractual and technological restrictions. So even if an extended doctrine of implied consent was enlivened to allow sharing of access details, the question becomes whether the doctrine can override express licensing terms, including an express term that restricts the existence of imputed consent. Essentially this illustrates a well-known conflict: freedom of contract and copyright user rights. As discussed at the beginning of this article, the concept of implied consent clearly conflicts with the idea of freedom to contract. Thus, it is not surprising that courts are generally reluctant to impute consent when this would override express terms of the contract. Some assistance can be taken from the commentary's discussion of EULAs overriding copyright exceptions and limitations. ${ }^{127}$

Even if there are statutory limits implemented barring contractual override, there is discussion as to whether the reliance on TPMs by copyright holders and licensed distributors has the same effect as a contractual clause limiting the application of implied consent. ${ }^{128}$ Indeed, Art. 6(4) Information Society Directive requires Member States to take appropriate measures to ensure that the beneficiaries of exceptions and limitations can access copyright work. However, this is only in the absence of voluntary measures taken by rightsholders, meaning that the scope of copyright is determined by contracting parties. This conflict was also recently exemplified in the Digital Content Directive as Art. 10 states that where users are prevented to some extent from accessing digital content due to a third-party infringement, Member States shall ensure that the user is entitled to remedies for the lack of conformity. ${ }^{129}$ However, the Digital Content Directive further complicates the accessibility to digital content as there is also a caveat that national law can nullify or rescind the contract for the supply of digital content in such cases, meaning that such remedies are unavailable to users.

Given the relationship between implied consent and exhaustion, the extent to which the CJEU encourages rights holders to override lawful exhaustion via TPMs should also be considered. The Court's proportionate approach to TPMs in Nintendo v. PC Box seems to indicate that there are circumstances where reliance on TPMs is a better alternative to defend against unlawful distributions of digital content than copyright infringement. Following UsedSoft, commentary suggested that the ruling proposes that exhaustion can be viewed as a limit on TPMs that restrict software after first sale. ${ }^{130}$ However, Tom Kabinet has restricted the application of exhaustion

\footnotetext{
127 Oprysk and Sein (2020), p. 594. (1998), p. 121.

128 Favale (2011), p. 306.

129 Directive (EU) 2019/770 of the European Parliament and of the Council of 20 May 2019 on certain aspects concerning contracts for the supply of digital content and digital services.

130 Ghosh and Calboli (2018), p. 165.
} 
to digital content, excluding software as lex specialis. The result is that the role of TPMs within digital content licensing agreements has been strengthened to the dismay of users.

However, this article has also discussed the status of an extended doctrine of implied consent as a fundamental principle of both common and civil law jurisdictions. Thus, as copyrights are not absolute, there are limitations at least to copyright, based inter alia on fundamental principles. ${ }^{131}$ While this article has taken the first steps in outlining the extended doctrine of implied consent, it is clear that the next steps in defining this doctrine would be to consider the extent to which freedom of contract can limit the application of fundamental principles, such as implied consent, and the relationship such status has with TPMs.

\section{Conclusion}

This article began with the proposition that in the face of mounting legal uncertainty for copyright users, implied consent be broadened to strengthen their access to digital content. This required an exploration of the foundations of implied consent, namely through the evolution of implied licences in both common law and civil jurisdictions. While implied licences were shown to be initially successful in providing the structure for a balance to be struck between copyright interests, modern implied licences in copyright law flit between two perspectives: opt in and opt out. This characterisation of balancing copyright interests is not helpful as the burden of proof either rests on the copyright holder barring all uses, such as through a TPM, or on the user who must qualify for an exception or limitation in order to access the copyright work. This black and white approach to distributing and accessing digital content fails to effectively incentivise and support digital content markets while also ensuring that there are no digital boundaries for access for users. Indeed, the concept of access discussed at the beginning of this article illustrates the stark reality users must accept to access and interact with digital content.

However, by tracing the evolution of implied licences it became evident that one element of these licences has potential to redefine the threshold for balancing copyright interests. Consent based in contractual interpretation or through the principle of copyright authorisation is a main element of implied licences in the UK, the EU, Germany, the US and Australia. Thus, it was proposed that implied consent converges in all of these jurisdictions, emerging as a fundamental principle with the ability to act as a fair balance test. The challenges of implementing an extended doctrine of implied consent from the perspective of the doctrine of exhaustion were also considered given its relationship with consent. Despite the finding in Tom Kabinet that the doctrine of exhaustion pursuant to the Information Society Directive does not apply to digital copies, the earlier exhaustion cases demonstrated a willingness on behalf of the CJEU to construe consent broadly, in the context of implementing and maintaining the single market.

\footnotetext{
${ }_{130}$ Ghosh and Calboli (2018), p. 165.

131 Grynberg (2010).
} 
This broad interpretation of consent, in addition to the status of the extended doctrine of implied consent as a fundamental principle, served as the legal foundation of the proposed doctrine. The thresholds of the doctrine were illustrated in reference to an example which illustrated users' experience of accessing digital content. The position under the Information Society Directive as it stands was compared to the potential application of an extended doctrine of implied consent. It became clear that the proposed doctrine's focus on the subsequent use could provide a more balanced and holistic approach to copyright interests in the digital age by focusing on relevant factors of such use. Further, that the doctrine's status as a fundamental principle could to some extent respond to the challenges of both contractual override and TPMs. It follows that the extended doctrine of implied consent has potential to successfully mediate between copyright holders and users in the digital environment, specifically regarding their access to digital content.

Open Access This article is licensed under a Creative Commons Attribution 4.0 International License, which permits use, sharing, adaptation, distribution and reproduction in any medium or format, as long as you give appropriate credit to the original author(s) and the source, provide a link to the Creative Commons licence, and indicate if changes were made. The images or other third party material in this article are included in the article's Creative Commons licence, unless indicated otherwise in a credit line to the material. If material is not included in the article's Creative Commons licence and your intended use is not permitted by statutory regulation or exceeds the permitted use, you will need to obtain permission directly from the copyright holder. To view a copy of this licence, visit http:// creativecommons.org/licenses/by/4.0/.

\section{References}

Afori O (2008) Implied license: An emerging new standard in copyright law. Santa Clara Comput High Tech Law J 25:275-325

Austen-Baker R (2017) Implied terms in English contract law, vol 2. Edward Elgar Publishing Limited, Cheltenham

Bildhäuser C (2015) User rights to photos: copyright as a weapon in e-commerce. JIPLP 10:709-712

Booton D (2011) The informal acquisition of copyright. Intellect Prop Quart 1:28-49

Chapdelaine P (2017) Copyright user rights. Contracts and the erosion of property. Oxford University Press, Oxford

Chapdelaine P (2018) Copyright user rights and remedies: an access to justice perspective. Laws 7:24-50

Clark B (2012) Google image search still does not infringe copyright, reaffirms Bundesgerichtshof. JIPLP 7:788-789

Edelman J (2016) The issues in construction of contracts. Judge's Speech at the Supreme and Federal Court Judges' Conference. https:/www.fedcourt.gov.au/digital-law-library/judges-speeches/ speeches-former-judges/justice-edelman/edelman-j-20160127 Accessed 29 July 2020

Favale M (2011) Approximation and DRM: can digital locks respect copyright exceptions. Int'l JL Info Tech 19:306-323

Ficsor M (2017) GS Media and Soulier: may the hyperlink conundrum be solved and the "new public", "specified technical means", and "restricted access" theories be neutralized through the application of the implied license doctrine and the innocent infringement defense? Auteurs média 1:18-27

Geiger G (2017) Copyright as an access right: Securing cultural participation through the protection of creators' interests. In: Giblin R, Weatherall K (eds) What if we could reimagine copyright. ANU Press, Canberra, pp 73-109

Ghosh S, Calboli I (2018) Exhausting intellectual property rights: A comparative law and policy analysis. Cambridge University Press, Cambridge

Ghosh S, Mezei P (2020) The elusive quest for digital exhaustion in the US and the EU: The CJEU's Tom Kabinet ruling a milestone or millstone for legal evolution? Hung Yearb Int Eur Law 8:249-275 
Grynberg G (2010) Property is a two-way street: personal copyright use and implied authorization. Fordham L Rev 79:435-498

Guibault L (1998) Pre-emption issues in the digital environment: can copyright limitations be overridden by contractual agreements under European Law. In: Grosheide F, Boele-Woelki K (eds) Molengrafica nr. 11. Europees Privaatrecht. Opstellen over Internationale Transacties en Intellectuele Eigendom. Koninklijke Vermande, Lelystad

Guibault L (2002) Copyright limitations and contracts: an analysis of the contractual overridability of limitations oncopyright. Kluwer Law International, New York

Guibault L (2016) Individual licensing models and consumer protection. In: Hilty R, Liu K-C (eds) Exploring sensible ways for paying copyright owners. Springer, Berlin, pp 207-226

Heinzl B (2020) Radio stream aggregator TuneIn held to infringe rightholders' copyrights. JIPLP $15: 84-85$

Hill W (2013) Media monitoring, copyright and technology: implications of recent cases. JIPLP 8:764-770

Hojnik J (2017) Technology neutral EU law: Digital goods within the traditional goods/services distinction. IJLIT 25:63-84

Höppner H, Schaper F (2016) Moving towards a world of selfies? - A critical view of the European legal framework for the online use of third party images. GRUR Int. 7:633-639

Hua J (2014) Towards a more balanced approach: rethinking and readjusting copyright systems in the digital network era. Springer, Heidleberg

Jasiewicz M (2012) Copyright Protection in an Opt-Out World: Implied License Doctrine and News Aggregators. Yale L J 122:837-850

Jütte B (2017) Reconstructing European copyright law for the digital single market between old paradigms and digital challenges. Nomos/Hart, Baden-Baden

Karapapa S (2017) The requirement for a "new public" in EU Copyright Law. Eur Law Rev 1:63-81

Kiker C (2012) Amazon Cloud Player: the latest front in the cold war. JTLP 17:235-298

Leistner M, Antoine L (2018) Exhaustion and second-hand digital goods/contents. In: Heath C, Sanders A, Moerland A (eds) Intellectual property rights as obstacles to legitimate trade. Kluwer Law International, New York, pp 159-180

Low K, Loi K (2009) The many 'tests' for terms implied in fact: welcome clarity. L.Q.R. 125:561-567

Mezei P (2015) Digital first sale doctrine ante portas - exhaustion in the online environment. JIPITEC 6:23-71

Mysoor P (2018) Exhaustion, non-exhaustion and implied licence. IIC 49:656-684

Naylor D, Parris E (2013) After ReDigi: contrasting the EU and US approaches to the re-sale of secondhand digital assets. EIPR 35:487-490

Oprysk L, Sein K (2020) Limitations in end-user licensing agreements: Is there a lack of conformity under the new Digital Content Directive. IIC 52:594-623

Pappalardo K, Suzor N (2018) The liability of Australian online intermediaries. Sydney L Rev 40:469-498

Perzanowski A, Schultz J (2012) Copyright exhaustion and the personal use dilemma. Minnesota L Rev 96:2067-2143

Perzanowski A, Schultz J (2015) Reconciling intellectual and personal property. Notre Dame L Rev 90:1211-1264

Perzanowski A, Schultz J (2018) The end of ownership: Personal property in the digital economy. MIT Press Cambridge, Massachusetts

Picht P (2020) The EU Geo-blocking regulation from a competition law perspective. JECLP 11:244-254

Pihlajarinne T (2012) Setting the limits for the implied license in copyright and linking discourse - the European perspective. IIC 43:700-710

Quinn D (2014) Associated Press v. Meltwater: are courts being fair to news aggregators. Minn J L Sci Tech 15:1189-1219

Quintais J (2018) Untangling the hyperlinking web: In search of the online right of communication to the public. J World Intellect Prop 21:385-420

Rosati E (2015) Online copyright exhaustion in a post-Allposters world. JIPLP 10:673-681

Salisbury S (2016) The principle of freedom of contract: are the courts too interventionist. Manchester Rev L Crime Ethics 5:58-63

Savič M (2015) The CJEU Allposters case: beginning of the end of digital exhaustion? E.I.P.R. 37:389-394 
Savola P (2017) EU copyright liability for internet linking. J Intell Prop Info Tech \& Elec Com L 2:139-150

Sganga C (2015) EU copyright law between property and fundamental rights: a proposal to connect the dots. In: Caso R, Giovanella F (eds) Balancing copyright in the digital age: Comparative perspectives. Springer, Heidelberg, pp 1-26

Sieman J (2007) Using the implied license to inject common sense into digital copyright. NCL Rev 85:885-930

Stokes S (2019) Digital copyright: Law and practice, vol 5. Hart, Oxford

Stothers C (2007) Parallel trade in Europe: intellectual property, competition and regulatory law. Hart, Oxford

Stothers C (2012) When is copyright exhausted by a software licence? UsedSoft v. Oracle. EIPR 11:787-791

Strowel A (2009) Peer-to-peer file sharing and secondary liability in copyright law. Edward Elgar Publishing Limited, Cheltenham

Westkamp G (2007) Intellectual property, competition rules, and the emerging internal market: some thoughts on the European exhaustion doctrine. Intellect Prop Law Rev 11:291-335

Westkamp G (2012) Emerging escape clauses? Online exhaustion, consent and European copyright law. In: Rosén J (ed) Intellectual property at the crossroads of trade. Edward Elgar Publishing Limited, Cheltenham, pp 38-66

Westkamp G (2016) Exhaustion and internet as a distribution channel: the relationship between intellectual property and European law in search of clarification. In: Calboli I, Lee E (eds) Research handbook on intellectual property exhaustion and parallel imports. Edward Elgar Publishing Limited, Cheltenham, pp 498-517

Westkamp G (2017) One or several super-rights? The (subtle) impact of the Digital Single Market on a future EU copyright architecture. In: Liu KG, Hilty RM (eds) Remuneration of copyright owners: regulatory challenges of new business models. Springer, Heidelberg, pp 21-50

Publisher's Note Springer Nature remains neutral with regard to jurisdictional claims in published maps and institutional affiliations. 